\title{
The Effect of Raw Mesocarp Fibre Inclusion on the Durability Properties of Lightweight Foamed Concrete
}

\author{
Md Azree Othuman Mydin ${ }^{1, *}$ \\ ${ }^{1}$ School of Housing, Building and Planning, Universiti Sains Malaysia, Penang 11800, Malaysia \\ *Corresponding author: azree@usm.my
}

\author{
KEYWORDS \\ Bending \\ Foamed concrete \\ Mesocarp fibre \\ Porosity \\ Water absorption \\ SUBMITTED 31 March 2021 \\ REVISED 30 June 2021 \\ ACCEPTED 6 July 2021
}

\begin{abstract}
Researchers around the globe have recognised the potential need for lightweight, reliable, easy to use, affordable, and even more sustainable building materials. One of the vanguard proposals has been the procurement, development and use of alternative, non-conventional local building materials, which includes the possibility of utilising lightweight foamed concrete (LFC). LFC is excellent under compression but poor in tensile stress, as it produces multiple microcracks. LFC cannot withstand the tensile stress induced by applied forces without additional reinforcing elements. This research was conducted to examine the potential utilisation of oil palm mesocarp fibre-reinforced (OPMF) LFC in terms of its durability. Two densities, $600 \mathrm{~kg} / \mathrm{m}^{3}$ and $1,200 \mathrm{~kg} / \mathrm{m}^{3}$, were cast and tested with five different percentages of OPMF, which were $0.00 \%$ (control), $0.15 \%, 0.30 \%, 0.45 \%$ and $0.60 \%$. The parameters evaluated were water absorption, porosity, drying shrinkage, ultrasonic pulse velocity. The results revealed that the inclusion of OPMF in LFC helps to minimise water absorption and the porosity of LFC. Moreover, the inclusion of OPMF also improves the drying shrinkage and ultrasonic pulse velocity of LFC.
\end{abstract}

(c) The Author(s) 2021. This article is distributed under a Creative Commons Attribution-ShareAlike 4.0 International license.

\section{INTRODUCTION}

Lightweight foamed concrete (LFC) is a material low in mechanical properties compared with contemporary concrete of a normal weight (Serri et al. 2014). It can be defined as a cementitious material containing at least $20 \%$ by volume of mechanically trained moisture in the mortar slurry, in which air pores are fixed in the matrix utilising a suitable foam (Ramli et al. 2013; Mydin and Zamzani 2018). LFC can be created with the introduction of a foaming agent into a cement-based mortar (Claramunt et al. 2016). The foaming agent can be added, and the foam develops through a gentle yet rigorous mixing (Mydin et al. 2014). Alternatively, the foaming agent can be aerated before it is applied to the mixture (Musa et al. 2019).

LFC has gained a large amount of attention for its high flowability, low self-weight, lower use of aggregate, low strength, and its thermal insulation (Suhaili and Mydin 2020). Moreover, LFC is an environmentally friendly material because of its minimal usage of aggregate and high potential to incorporate waste material such as fibre (Raj et al. 2019). The high amount of cement usage and low elastic modulus of the aggregate in the production of LFC increases its drying shrinkage (Mydin et al. 2018). The addition of fibre into LFC is to strengthen its durability properties. Adding small volumetric fractions of short fibres can reduce the impact of early-age reduction of the concrete's durability. It can also restrict the growth of cracks under loads.

Natural fibre-reinforced composites have many benefits, such as being light in weight, affordable, highly sturdy, and having good strength and inflexibility. Oil palm meso- carp fibre (OPMF) has a potential to be used as an additive in LFC to enhance its durability properties. OPMF acts as a reinforcement to improve its composites' behaviour. There are some advantages to using fibre introduced into the concrete, such as the resulting composites offering more flexural strength compared with that of a reinforcement bar (Risdanareni et al. 2016). In addition, it will increase the impact toughness and post-failure integrity, and enhance the bending strength of the composites. It will also arrest the propagation of micro-cracks, increasing the tensile strength of concrete and reducing air and water voids (Mohamad et al. 2018).

The durability properties of concrete, such as porosity, abrasion, resistance to weathering action, ultrasonic pulse velocity, and chemical attack, are mostly improved by incorporating natural or synthetic fibres. Synthetic fibres including polypropylene, steel, glass, and carbon fibres have been studied extensively in LFC (Awang et al. 2015; Bing et al. 2012; Falliano et al. 2019; Awang and Ahmad 2014). However, synthetic fibre in LFC is not advisable for numerous reasons. Synthetic fibre such as that from steel is heavy and may sink and lead to high thermal conductivity in the mixture of high-porosity LFC. Most synthetic fibres are weighty in comparison with natural fibres. Meanwhile, the synthesis of synthetic fibres from petroleum products releases a high level of $\mathrm{CO}_{2}$ and generates environmental pollution and, consequently, is not sustainable.

There has been a wide application of natural fibres in producing lightweight concrete due to the increasing interest in natural fibres in adhering to a more environmental and cost-effective value in construction industries. How- 
ever, it should be understood from a structural standpoint that the primary purpose of adding fibre in cementitious material is to improve the durability of engineering properties. Natural fibre can play an important role in enhancing the matrix bond that will help to develop the tensile strength and structural integrity of the concrete (Lau et al. 2018). Moses et al. (2015) determined that the finest fibres have a very good essence that assists to improve the strength and qualities of concrete. Their study also revealed that the use of natural fibre can help to improve shrinkage and ductility. Reinforced concrete with the inclusion of fibres is able to reduce plastic shrinkage and improve durability, which is in line with the study conducted by Grégoire et al. (2019), which postulated that the flexural resistance and durability of concrete will be improved by incorporating fibres into the concrete.

Malaysia produces a surplus of 15,000 tonnes of solid waste per day in the form of biomass that consists of forest and mill residues, agricultural waste, wood wastes, and municipal wastes. The increase in the quantity of agricultural industries in Malaysia chains economic growth positively, but it distresses the environment defiantly by producing large amounts of wastes. Globally, 1,000 million tonnes of agricultural waste are reportedly produced in a year and in Malaysia, 1.2 million tonnes of agricultural waste is disposed into landfills every year (Yusoff et al. 2010).

OPMF refers to agricultural waste or by-products that can be obtained through the distribution of oil palm and can be accumulated in a large amount in Malaysia. It should be understood that OPMF is often discarded in the form of agricultural waste. Yet, several schemes concentrating on the lower cost of materials have been recommended despite the important need of green concrete production and a reasonably priced housing system both for people who live in the countryside as well as those residing in metropolitan areas in Malaysia. As a result, it has been recommended that agricultural wastes and residues should be utilized as partial or full replacement of building materials (Balasubramanian et al. 2015). Accordingly, it is crucial to note that OPMF has the potential to be utilized as substitute coarse aggregate in foamed concrete for the purpose of improving durability properties. Currently, there is a dearth

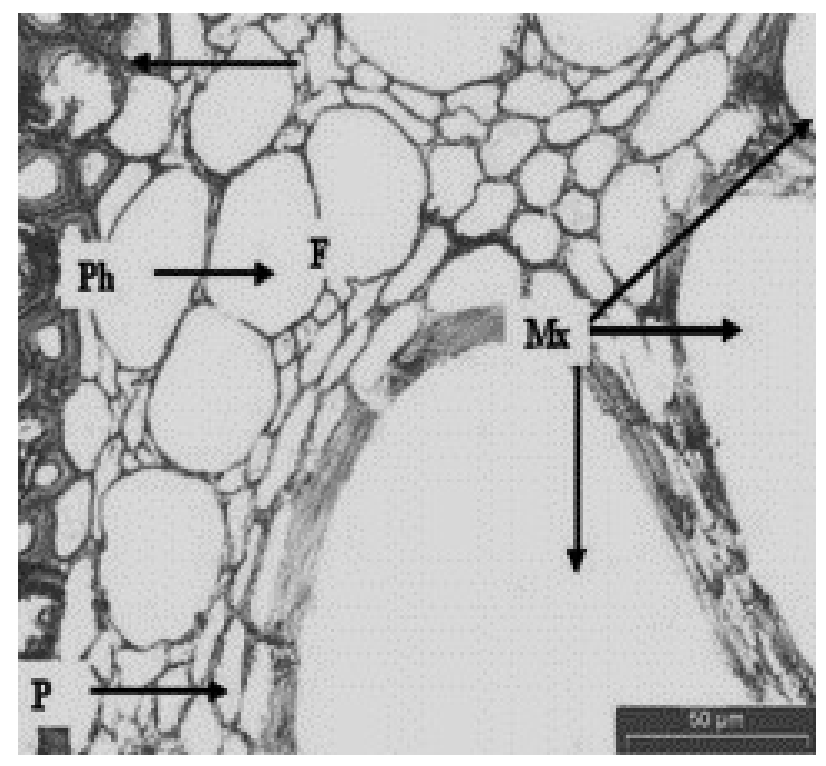

FIGURE 1. Transverse section of mesocarp fibre. of studies in the utilization of OPMF in the production of foamed concrete, though it has been reported to have good pozzolanic properties necessary for the replacement of cement or as an additive in foamed concrete. Hence, this research was executed to grasp the potential utilization of oil palm mesocarp fibre in LFC with the intention of enhancing its durability properties.

\section{MATERIALS AND METHODS}

\subsection{Materials}

For this particular experimental work, ordinary portland cement was utilized in accordance with BS12 Standard (British Standards Institution 1996), which was supplied by YTL Castle Cement Marketing Sdn Bhd. All of the cement used was in good condition and stored in a covered area. Next, the fine aggregate used was natural fine sand obtained from a local distributor. The sand was fine with a maximum width of $2 \mathrm{~mm}$ and a 600 -micron sieve, and a passage of $60 \%$ to $90 \%$. The suitability of the sand had to follow BS822:1992. The foaming agent used was a protein-based foaming agent, namely Noraite PA-1. This Noraite PA-1 was chosen as the foaming agent due to its stability and smaller bubbles, which create a stronger bubble bonding structure compared with a synthetic-based protein. Next, the tap water used had to be clear and clean. Water was required for the preparation of the mortar, mixing the foam concrete, and the curing work. The water-cement ratio used for this research was 0.45 , because this ratio can achieve reasonable workability, based on previous research. Last but not least, the fibre used was oil palm mesocarp fibre, which was freshly collected from an industrial unit after processing. The mesocarp fibre was covered by a skin of grease which

TABLE 1. Chemical composition, physical properties, and mechanical properties of oil palm mesocarp fibre (OPMF).

\begin{tabular}{|c|c|}
\hline \multicolumn{2}{|c|}{ Chemical composition } \\
\hline Composition & Dry weight (\%) \\
\hline Lignin & 20.1 \\
\hline Cellulose & 42.2 \\
\hline Hemicellulose & 28.8 \\
\hline Extractives & 4.1 \\
\hline Ash & 2.0 \\
\hline Moisture & 2.8 \\
\hline \multicolumn{2}{|c|}{ Physical properties } \\
\hline Component & Properties \\
\hline Fibre length & $15 \mathrm{~mm}$ \\
\hline Fibre diameter & $309 \mu \mathrm{m}$ \\
\hline Lumen width & $17.45 \mu \mathrm{m}$ \\
\hline Density & $0.82 \mathrm{~g} / \mathrm{cm}^{3}$ \\
\hline Runkel ratio & 0.275 \\
\hline Fibril angle $\left(^{\circ}\right)$ & 42 \\
\hline \multicolumn{2}{|c|}{ Mechanical properties } \\
\hline Component & Properties \\
\hline Tensile strength (MPa) & 139.6 \\
\hline Young's modulus (MPa) & 14300 \\
\hline Elongation at break (\%) & 9.76 \\
\hline
\end{tabular}


TABLE 2. LFC mix proportions at densities of $600 \mathrm{~kg} / \mathrm{m}^{3}$ and $1,200 \mathrm{~kg} / \mathrm{m}^{3}$.

\begin{tabular}{|c|c|c|c|c|c|c|}
\hline Dry density $\left(\mathrm{kg} / \mathrm{m}^{3}\right)$ & OPMF (\%) & Mix ratio (C:S:W) & OPMF (kg) & Cement (kg) & Fine sand (kg) & Water $(\mathrm{kg})$ \\
\hline \multirow[t]{5}{*}{600} & 0.00 & $1: 1.5: 0.45$ & 0.000 & 20.72 & 31.08 & 9.32 \\
\hline & 0.15 & 1:1.5:0.45 & 0.098 & 20.72 & 31.08 & 9.32 \\
\hline & 0.30 & 1:1.5:0.45 & 0.195 & 20.72 & 31.08 & 9.32 \\
\hline & 0.45 & 1:1.5:0.45 & 0.293 & 20.72 & 31.08 & 9.32 \\
\hline & 0.60 & $1: 1.5: 0.45$ & 0.390 & 20.72 & 31.08 & 9.32 \\
\hline \multirow[t]{5}{*}{1200} & 0.00 & 1:1.5:0.45 & 0.000 & 40.22 & 60.33 & 18.10 \\
\hline & 0.15 & 1:1.5:0.45 & 0.178 & 40.22 & 60.33 & 18.10 \\
\hline & 0.30 & $1: 1.5: 0.45$ & 0.356 & 40.22 & 60.33 & 18.10 \\
\hline & 0.45 & 1:1.5:0.45 & 0.534 & 40.22 & 60.33 & 18.10 \\
\hline & 0.60 & $1: 1.5: 0.45$ & 0.712 & 40.22 & 60.33 & 18.10 \\
\hline
\end{tabular}

would cause fungal growth and spoilage. The fibre needed to be washed until it was free from the grease. The mesocarp fibre was then placed under the sun to dry. Figure 1 visualizes the transverse section of the OPMF considered in this investigation.

Table 1 shows the chemical composition, physical properties, and mechanical properties of OPMF. OPMF has a high cellulose percentage that may assist greatly when in composite action with the cement matrix. According to Ardanuy et al. (2015), fibres with high cellulose content, generally, present a low deformation capacity with excellent young's modulus and this is confirmed by the experimental evidence achieved in their study. Additionally, it was reported that the tensile strength and young's modulus of plant fibre generally increases with increasing cellulose content of the fibres (Yusoff et al. 2010).

\subsection{LFC mix design}

A total of 10 LFC mixes consisting of two densities (600 $\mathrm{kg} / \mathrm{m}^{3}$ and $1,200 \mathrm{~kg} / \mathrm{m}^{3}$ ) were fabricated. These two densities were chosen to represent low density and medium density LFC, which tend to have low durability properties compared with high density foamed concrete (more than $1400 \mathrm{~kg} / \mathrm{m}^{3}$ ). The volume fractions of the OPMF utilized in this laboratory assessment were $0.00 \%$ (control), $0.15 \%$, $0.30 \%, 0.45 \%$, and $0.60 \%$. A range of fibre volume fraction between $0.15 \%$ and $0.60 \%$ was opted in this research, owing to a previous pilot study where the researcher found that the addition of an OPMF volume fraction of more than $0.6 \%$ led to agglomeration and non-uniform dispersion of fibres during mixing. The sand-cement (C:S) ratio used was 1:1.5 and the water-cement $(\mathrm{W}: \mathrm{C})$ ratio used was kept constant at 0.45 for all of the mixes. Table 2 shows the mix proportions of this study.

\subsection{Mixing process}

The general practices implemented by normal concrete mixing were utilized in the mixing process of LFC in this investigation; hence, all the mixings were performed manually. Subsequently, the weight for cement, sand, and OPMF were evaluated, and then mixed in a concrete mixer until they were homogeneously mixed. The next step involved the weighting of the water that was poured into the dry mix. The mixer was run until the wet mix was blended evenly. In the next step, a certain amount of foam was measured and regularly included into the wet mix until the ideal thickness was achieved. Meanwhile, a flow table test was completed before the new LFC was filled into the mould, while some grease was added into the steel mould to enable the LFC to be removed easily. After being poured into the steel mould, the LFC was left to dry. It is important to note that LFC needs about $24 \mathrm{~h}$ to dry before it is ready to be removed.

\subsection{Experimental setup}

Several tests were performed to inspect the durability properties of LFC, namely a porosity test, water absorption test, drying shrinkage test, and ultrasonic pulse velocity test. Table 3 displays the details of the samples and standard codes referred to in these tests for the durability properties.

\subsubsection{Porosity test}

A porosity test was performed using the vacuum saturation method demonstrated by Kearsley and Wainwright (2001). This test was carried out on day-28 by immersing the specimen into a vacuum desiccator. The purpose of this test was to determine the percentage of air voids in the LFC specimens of different densities, which will influence their strength. The lower the percentage of porosity in LFC, the higher its strength. This is because the presence of more air voids in the cement matrix will cause it to be more brittle and susceptible to cracks. Three specimens of LFC with a diameter of $45 \mathrm{~mm}$ and height of $50 \mathrm{~mm}$ were placed in an oven to remove moisture for $72 \mathrm{~h}$ or until no changes in weight were recorded. Then, each specimen was cooled, and its weight recorded as $W_{d r y}$. The specimens were fully immersed in a vacuum chamber for $72 \mathrm{~h}$ or until no visible

TABLE 3. Mechanical and durability properties tests.

\begin{tabular}{lll}
\hline Type of Experiment & Sample size & Testing Code \\
\hline Porosity test & Cylinder $(45 \mathrm{~mm}$ diameter $\times 50 \mathrm{~mm}$ height) & BS 1881: Part 122 (British Standards Institution 1983) \\
Water absorption test & Cylinder $(75 \mathrm{~mm}$ diameter $\times 100 \mathrm{~mm}$ height) & BS 1881: Part 122 (British Standards Institution 1983) \\
Drying shrinkage test & Prism $(75 \mathrm{~mm} \times 75 \mathrm{~mm} \times 275 \mathrm{~mm})$ & ASTM C878 (ASTM C878/C878M-14a 2014) \\
UPV test & Prism $(100 \mathrm{~mm} \times 100 \mathrm{~mm} \times 500 \mathrm{~mm})$ & BS 12504: Part 4 (British Standards Institution 2004) \\
\hline
\end{tabular}


bubbles appeared. The weights of the specimens in the water $\left(W_{s, a}\right)$ and in the air $\left(W_{s, w}\right)$ were recorded. Equation 1 was used to measure the percentage of porosity in the LFC. The average value of the three specimens was recorded as the final result for the total porosity test.

$$
\text { Total porosity }(\%)=\left(\frac{W_{s, a}-W_{d r y}}{W_{s, a}-W_{s, w}}\right) \times 100 \%
$$

where $W_{s, a}$ is the weight of the saturated sample in air, $W_{d r y}$ is the weight of the oven-dried sample, and $W_{s, w}$ is the weight of the saturated sample in water.

\subsubsection{Water absorption test}

The water absorption test is important for determining the percentage of water absorbed by an LFC sample at a given time. Furthermore, a higher percentage of water absorption in LFC can affect its density and compressive strength. The water absorption test was carried out as prescribed in BS 1881-122 (British Standards Institution 1983). Cylindricalshaped specimens $(75 \mathrm{~mm} \varnothing \times 100 \mathrm{~mm} \mathrm{~h}$ ) were used in this study. At the aging day of the test, three specimens were unwrapped and oven-dried for $72 \mathrm{~h}$. Then, the weight of each cooled oven-dried specimen was recorded as $W_{d}$, and then fully submerged in a water tank for $30 \mathrm{~min}$. Next, a dry cloth was used to remove any excess water present on the test specimen and its weight was recorded in a saturated condition as $W_{s}$. The water absorption was expressed as a percentage as $W_{a}$, and was calculated using Equation 2. The average water absorption of these three samples was taken as the final result for the water absorption test.

$$
\text { Water absorption }(\%)=\left(\frac{W_{s}-W_{d}}{W_{d}}\right) \times 100 \%
$$

where $W_{s}$ is the saturated surface dry weight, and $W_{d}$ is the oven-dried weight.

\subsubsection{Drying shrinkage test}

The drying shrinkage test was carried out using a Mitutoyo (Kawasaki, Japan) digital indicator with a $298 \mathrm{~mm}$ reference bar according to the ASTM C157 standard. There were three samples of the prism $(75 \times 75 \times 285 \mathrm{~mm})$ installed with a pair of steel screws and cap nuts. After demoulding, the LFC specimens were placed in the length comparator as setup in and rotated anti-clockwise to get the data. The

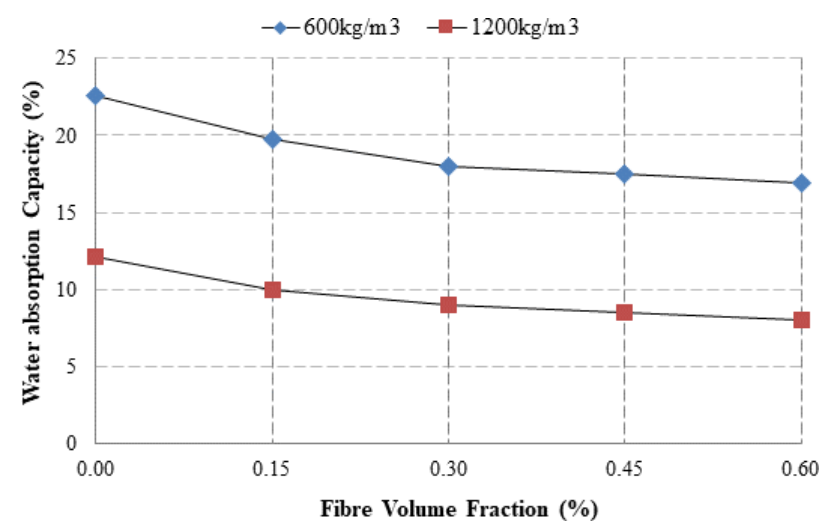

FIGURE 2. Influence of different percentages of mesocarp fibre on water absorption of LFC. readings were recorded as $L i$. Then, the steps were repeated for the next testing ages, namely days $1,3,7,14,21$, 28, and 56. These readings were recorded as $L x$ where $x$ represents the subsequent testing age.

\subsubsection{Ultrasonic pulse velocity test}

The ultrasonic pulse velocity (UPV) test was carried out by measuring the propagation velocity of a transmitted longitudinal ultrasonic pulse across the cross-sectional area. Mortar prisms were measured at the dimensions of 100 $\mathrm{mm} \times 100 \mathrm{~mm} \times 500 \mathrm{~mm}$. An electro-acoustical transducer was used to examine transmission of the ultrasonic pulse. It was held in contact with an electrical signal by a second transducer after the pulse traversing a known path length in the specimen. An electromagnet transducer was then showed the transmitted time and velocity. The standard procedures were conducted according to the standard prescribed in BS EN 12504-4 (British Standards Institution 2004). A mortar prism with the dimensions of $100 \mathrm{~mm}$ $\times 100 \mathrm{~mm} \times 500 \mathrm{~mm}$ was constructed for all mix designs and examined at day 7, day 28, day 60, and day 180 during the curing stage. Readings were taken and the average velocity of the UPV result was taken.

\section{RESULTS AND DISCUSSION}

\subsection{Water absorption}

The results of the water absorption capacity test of LFC at 28 days are shown in Figure 2. The general trend of the graph was a steady decrease from plain LFC to the LFC with $0.60 \%$ of OPMF. The plain LFC at both $600 \mathrm{~kg} / \mathrm{m}^{3}$ and $1,200 \mathrm{~kg} / \mathrm{m}^{3}$ densities showed the highest water absorption capacity ( $22.6 \%$ and $12.1 \%$, respectively). The inclusion of $0.15 \%$ of OPMF at both $600 \mathrm{~kg} / \mathrm{m}^{3}$ and $1,200 \mathrm{~kg} / \mathrm{m}^{3} \mathrm{den}-$ sities showed the second-highest water absorption capacity, $19.8 \%$ and $10.0 \%$, respectively. Adding $0.30 \%$ of OPMF into both $600 \mathrm{~kg} / \mathrm{m}^{3}$ and $1,200 \mathrm{~kg} / \mathrm{m}^{3}$ achieved a water absorption capacity of $18.0 \%$ and $9.0 \%$, respectively. Furthermore, the inclusion of $0.45 \%$ of OPMF, at both $600 \mathrm{~kg} / \mathrm{m}^{3}$ and $1,200 \mathrm{~kg} / \mathrm{m}^{3}$ densities, showed the second-lowest water absorption capacity, at $19.8 \%$ and $10.0 \%$, respectively. The lowest water absorption capacity was with the inclusion of $0.60 \%$ of OPMF at both $600 \mathrm{~kg} / \mathrm{m}^{3}$ and $1,200 \mathrm{~kg} / \mathrm{m}^{3}$ densities (16.9\% and $8.0 \%$, respectively). These results collectively showed that the higher the percentage of OPMF added in the LFC, the lower the water absorption capacity of the LFC. From the overall perspective, the water ab-

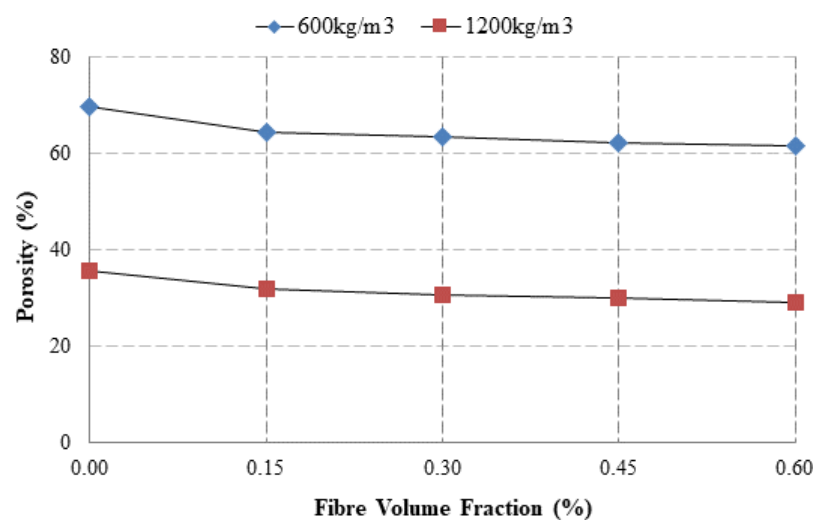

FIGURE 3. Influence of different percentages of mesocarp fibre on poros ity of LFC. 
sorption capacity for the density of $600 \mathrm{~kg} / \mathrm{m}^{3}$ was higher than that for $1,200 \mathrm{~kg} / \mathrm{m}^{3}$. This is because the $1,200 \mathrm{~kg} / \mathrm{m}^{3}$ density has a higher volume of foam. The sorptivity decreases with an increase in foam volume because the former is characterised by capillary suction, and air entrained does not contribute to the mechanism of transport (Hamad 2014). Meanwhile, the tortuosity is usually reduced, resulting from a lower foam volume.

The lower rate of water absorption of LFC, particularly when it contained a higher OPMF volume fraction, was due to a reduction of the size of capillary pores with the addition of the higher volume fraction of OPMF. Elsaid et al. (2011) reported that a higher content of kenaf fibre managed to prevent water from penetrating into concrete due to the small size of pores and volume. Meanwhile, the OPMF lost its dampness and shrunk back onto their sizes due to the drying process. Rahman et al. (2008) found that the C-S-H gel creation in a concrete matrix with a higher content of natural kenaf fibre abridged the pore size, which resulted in lower water absorption. Water absorption occurred because of the presence of fine void in the LFC.

\subsection{Porosity}

The results of the porosity percentage test of LFC at 28 days are shown in Figure 3. The general trend of the graph was a steady decrease from plain LFC to $0.60 \%$ of OPMF. The

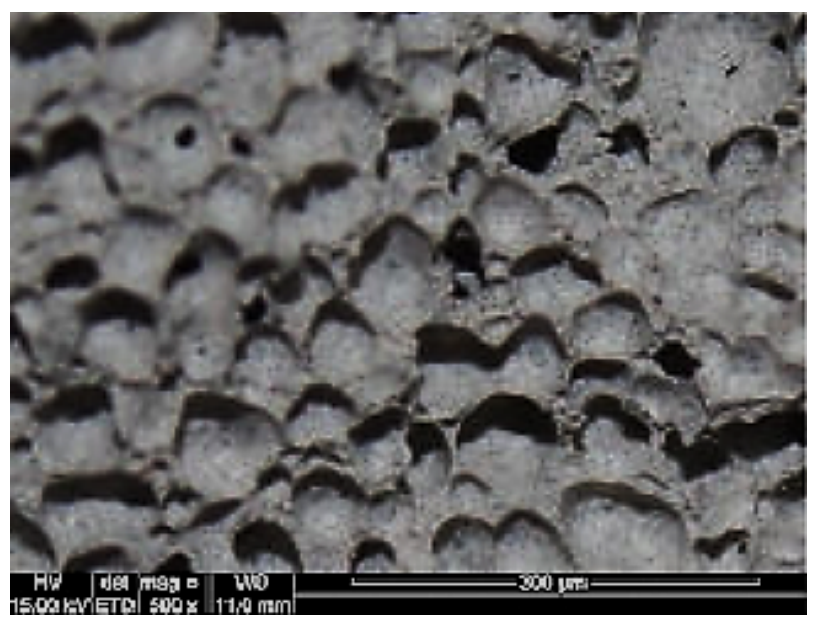

(a)

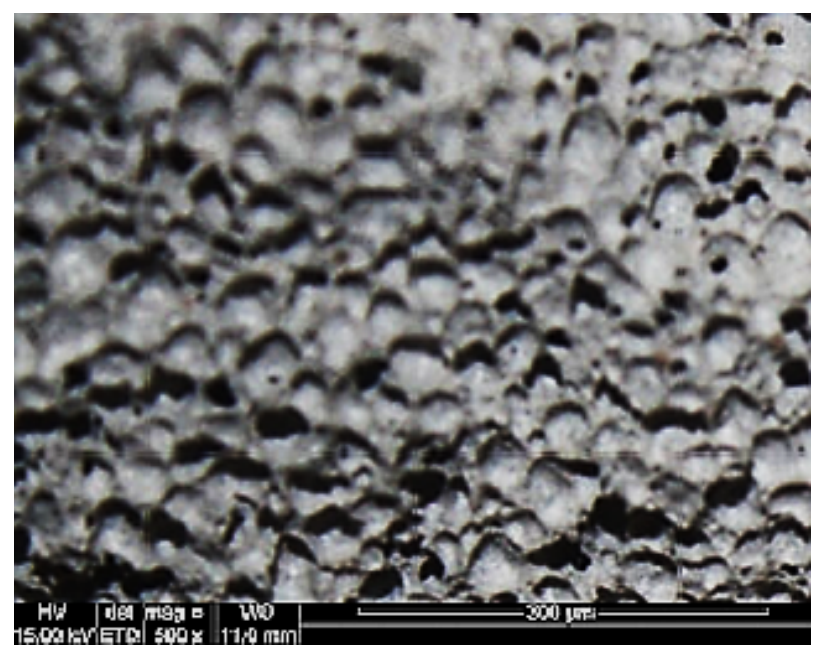

(b)

FIGURE 4. Pore size distribution of (a) $600 \mathrm{~kg} / \mathrm{m}^{3}$ density LFC (control specimen) and (b) $1,200 \mathrm{~kg} / \mathrm{m}^{3}$ density LFC (control specimen). plain LFC, at both $600 \mathrm{~kg} / \mathrm{m}^{3}$ and $1,200 \mathrm{~kg} / \mathrm{m}^{3}$ densities, showed the highest porosity percentage, $69.7 \%$ and $35.5 \%$, respectively. Figure $4 \mathrm{a}$ and Figure $4 \mathrm{~b}$ shows the SEM images of $600 \mathrm{~kg} / \mathrm{m}^{3}$ and $1,200 \mathrm{~kg} / \mathrm{m}^{3}$ densities of LFC. It can be seen that the average pore sizes for $600 \mathrm{~kg} / \mathrm{m}^{3} \mathrm{LFC}$ were larger than the $1,200 \mathrm{~kg} / \mathrm{m}^{3}$ LFC density. This was due to the amount of foam added into the mix. A lower density needs a higher content of foam to be included, hence the pore sizes were greater compared with the higher density.

The inclusion of $0.15 \%$ of OPMF at both $600 \mathrm{~kg} / \mathrm{m}^{3}$ and $1,200 \mathrm{~kg} / \mathrm{m}^{3}$ densities showed the second-highest porosity percentage, at $64.4 \%$ and $31.9 \%$, respectively. Meanwhile, adding $0.30 \%$ of OPMF achieved a porosity percentage of $63.5 \%$ and $30.7 \%$, respectively. The addition of $0.45 \%$ of OPMF at $600 \mathrm{~kg} / \mathrm{m}^{3}$ and $1,200 \mathrm{~kg} / \mathrm{m}^{3}$ densities resulted in the second-lowest porosity percentage $(62.4 \%$ and $30.1 \%$, respectively). The lowest porosity percentage was the inclusion of $0.60 \%$ of OPMF at both $600 \mathrm{~kg} / \mathrm{m}^{3}$ and 1,200 $\mathrm{kg} / \mathrm{m}^{3}$ densities, at $61.5 \%$ and $29.1 \%$, respectively. This indicates that the higher the percentage of OPMF incorporated into the LFC, the lower the porosity percentage of the LFC. The proportion of larger voids decreased, leading to a narrower air void size distribution. In addition, for a given density, the additives in combination led to an increase in void numbers by preventing their merging, and which produced a narrower void size distribution compared with a corresponding conventional mix. From the overall viewpoint, the porosity percentage for the $600 \mathrm{~kg} / \mathrm{m}^{3}$ density was higher than that of the $1,200 \mathrm{~kg} / \mathrm{m}^{3}$ density. Many researchers have stated that a higher amount of foam agent has a sub-
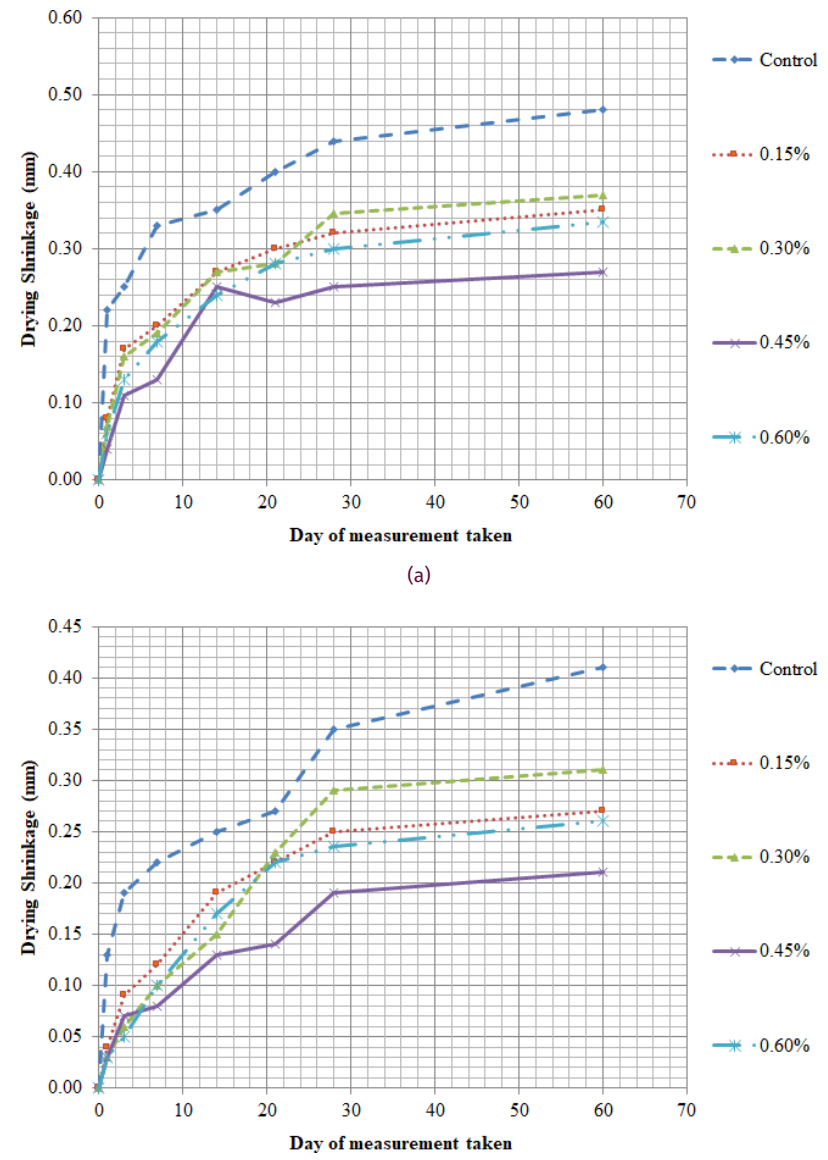

(b)

FIGURE 5. Influence of different percentages of fibre on drying shrinkage of (a) $600 \mathrm{~kg} / \mathrm{m}^{3}$ density and (b) $1,200 \mathrm{~kg} / \mathrm{m}^{3}$ density. 
stantial impact on porosity (Jalal et al. 2017), because the foam composition is largely related to the shape, size, spacing of the air, size distribution, and volume of microspores.

This finding is supported by a study undertaken by Amran (2020), who reported an increase in porosity as the fibre content increases. However, apart from this claim, the porosity of LFC is mostly influenced by the quantity of foam introduced into the based mix (Amran et al. 2015). Additionally, as was verified by Castillo-Lara et al. (2020), the reduction in porosity with the addition of natural fibres reported in this study ranged between $1.28 \%$ and $6.15 \%$, which is very small and negligible. On another note, the alteration and morphology variation of the OPMF causes the reduction in porosity of LFC. A higher volume fraction of fibre in concrete assists to bridge the matrix, hence reducing the porosity of the concrete (Nambiar and Ramamurthy 2007).

\subsection{Drying shrinkage}

Figures $5 \mathrm{a}$ and $5 \mathrm{~b}$ show the results of the drying shrinkage percentage test at densities of $600 \mathrm{~kg} / \mathrm{m}^{3}$ and $1,200 \mathrm{~kg} / \mathrm{m}^{3}$. As an overall observation, at day- 7 , the drying shrinkage of the LFC had obviously increased. However, the drying shrinkage of LFC slightly increased between day-28 and day-56. This was because the concrete was not fully hardened at day-7, whereas the LFC was $100 \%$ hardened after day-28 and the shrinkage of the LFC began to slow. Overall, the drying shrinkage value of the $600 \mathrm{~kg} / \mathrm{m}^{3}$ density was higher than that of $1,200 \mathrm{~kg} / \mathrm{m}^{3}$. Referring to the results

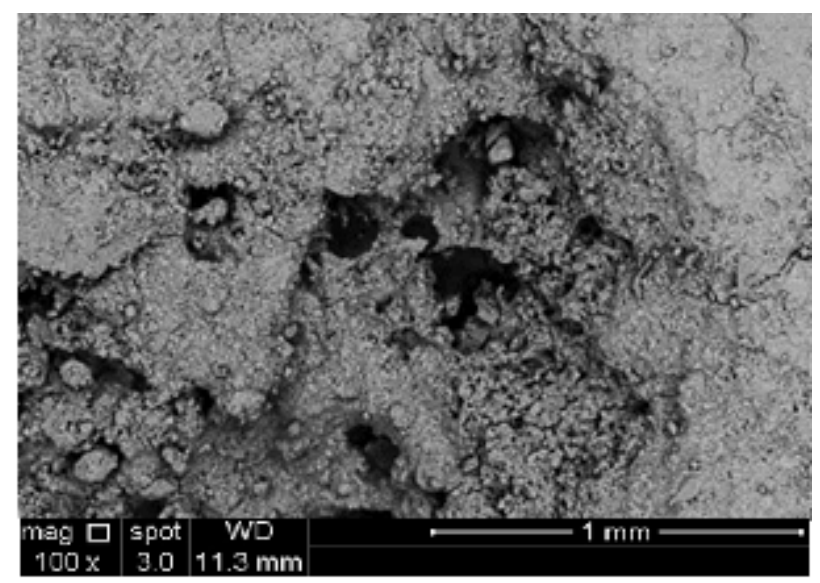

(a)

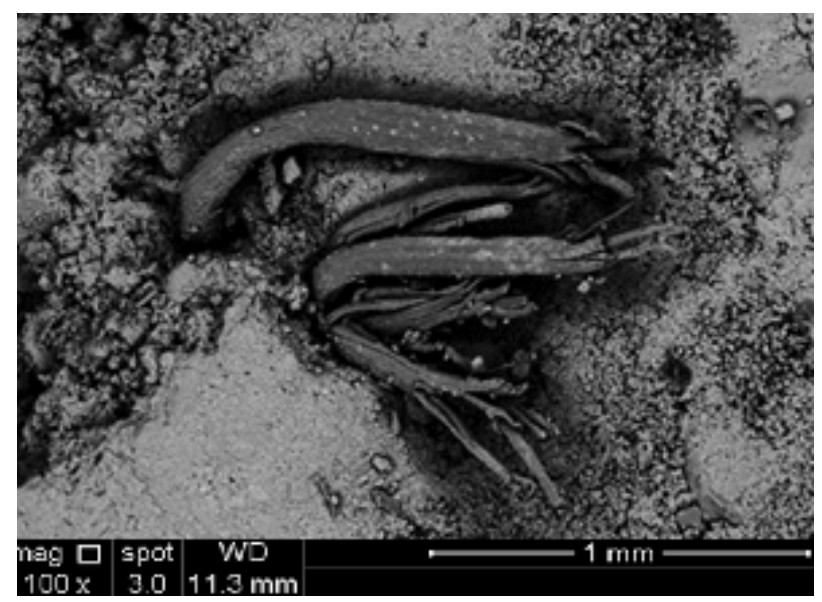

(b)

FIGURE 6. (a) SEM image of $1,200 \mathrm{~kg} / \mathrm{m}^{3}$ density LFC with the addition of $0.45 \%$ of mesocarp fibre; (b) close-up view. obtained, the LFC had the lowest value of drying shrinkage percentage while the plain LFC had the highest value of drying shrinkage. A higher value of drying shrinkage is an issue for concrete because it can cause cracking in the future. From this result, it can be seen that adding OPMF to LFC can reduce the drying shrinkage in LFC.

From the overall viewpoint, the drying shrinkage for the density of $600 \mathrm{~kg} / \mathrm{m}^{3}$ was higher than that of 1,200 $\mathrm{kg} / \mathrm{m}^{3}$. This is because the foam volume was lower for the density of $1,200 \mathrm{~kg} / \mathrm{m}^{3}$ compared with that of 600 $\mathrm{kg} / \mathrm{m}^{3}$. It has been reported in previous research that an increase in the foam volume reduces the shrinkage due to the growth in pore sizes (Jhatial et al. 2017). A reduction of up to $36 \%$ in drying shrinkage was found as the foam volume rose to $50 \%$ of the total volume. Figures $6 \mathrm{a}$ and $6 \mathrm{~b}$ demonstrate the SEM result of LFC with the addition of $0.45 \%$ of mesocarp fibre. We can observe that the inclusion of mesocarp fibre plays an important role in filling the capillary pores of LFC, thus reducing the pore size, as well (Mydin 2016). The addition of $0.45 \%$ of mesocarp fibre was the optimum volume fraction that resulted in the best durability properties.

These findings are supported by Zamzani (2019), who found that the addition of $0.3-0.5 \%$ volume fraction of coir fibre in LFC provides the best outcomes in lessening shrinkage compared with the control mix of LFC of $650 \mathrm{~kg} / \mathrm{m}^{3}$ density. The coir fibre reacts as an aggregate or filler that gives a compact composition of the microstructure, which in this way lessens as well as decreases the size and measures of pores. Cracking occurring due to the effect of shrinkage is a rather multifaceted mechanism of deformation that is predisposed by factors such as rate of shrinkage, size of the crack, level of restraint, strength development, and demulcent of the stress in the matrix. The utilization of natural fibres in concrete mixes is commonly seen as a deterrence technique for cracks formed in the external and internal layers of the hardened concrete (Zhang et al. 2001).

Natural fibres permit the bridging of cracks, which helps in increasing the ductility of the concrete composite after the post-cracking phase. The optimum volume fraction of fibre between $0.4 \%$ and $0.8 \%$ in concrete aims to produce stronger and tougher concrete, particularly improving the ductility and durability and mitigating cracking due to shrinkage (Combrinck and Boshoff 2013). Fibres have also been reported to upsurge the fatigue life cycle of cementitious composite structures. Fibre's inclusion in concrete is known to control cracking ascending from plastic shrinkage behaviour stirring in the cementitious matrix. Figure $6 \mathrm{~b}$ shows the close-up view of $1,200 \mathrm{~kg} / \mathrm{m}^{3} \mathrm{LFC}$

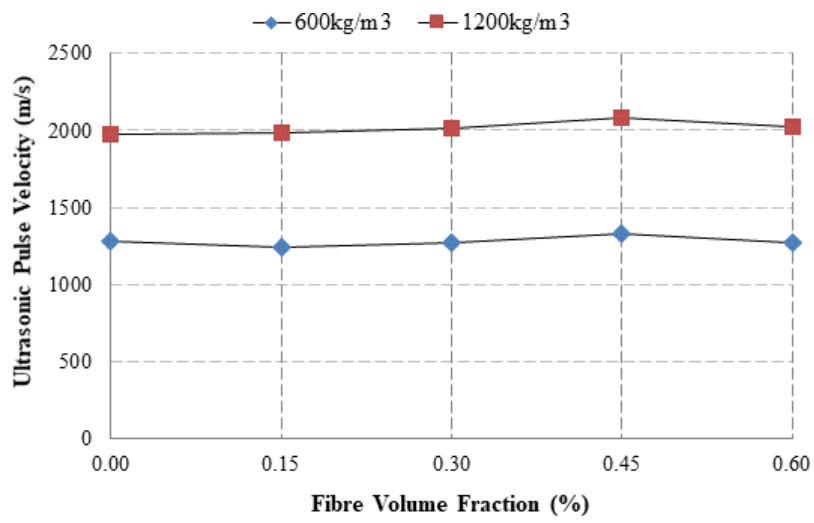

FIGURE 7. Influence of different percentages of mesocarp fibre on UPV of LFC. 
with the addition of $0.45 \%$ mesocarp fibre. Components of mesocarp fibres can be seen in the hardened cementitious matrix. The mitigation of drying shrinkage supports the concrete visually, and also by controlling and averting shrinkage cracks, which at the same time enhances the durability properties of concrete (Hindy et al. 1994).

\subsection{Ultrasonic pulse velocity}

The UPV results of the LFC at day-28 are shown in Figure 7. For the $600 \mathrm{~kg} / \mathrm{m}^{3}$ and $1,200 \mathrm{~kg} / \mathrm{m}^{3}$ densities, the inclusion of $0.45 \%$ of OPMF showed the highest UPV, which was 1,329 $\mathrm{m} / \mathrm{s}$ and $2,083 \mathrm{~m} / \mathrm{s}$, respectively. The highest UPV represents the highest quality LFC. Next, the inclusion of $0.15 \%$ of OPMF at both densities showed the lowest UPV $(1,242$ $\mathrm{m} / \mathrm{s}$ and $1,978 \mathrm{~m} / \mathrm{s}$, respectively). The lowest UPV represents the poorest quality LFC. The second-highest UPV was obtained without adding any percentage of OPMF, which was $1,284 \mathrm{~m} / \mathrm{s}$ for the density of $600 \mathrm{~kg} / \mathrm{m}^{3}$. For the density of $1,200 \mathrm{~kg} / \mathrm{m}^{3}$, the second-highest UPV was with the inclusion of $0.60 \%$ of OPMF $(2,024 \mathrm{~m} / \mathrm{s})$. Moreover, the second-lowest UPV was with the inclusion of $0.30 \%$ OPMF, $1,273 \mathrm{~m} / \mathrm{s}$ for the density of $600 \mathrm{~kg} / \mathrm{m}^{3}$. Meanwhile, for the $1,200 \mathrm{~kg} / \mathrm{m}^{3}$ density, the second-lowest UPV was with the addition of $0.15 \%$ of OPMF, at $1,981 \mathrm{~m} / \mathrm{s}$. Based on these results, the value of the ultrasonic pulse velocity influences the quality of the LFC. The higher the ultrasonic pulse velocity, the better the quality of LFC.

From the overall viewpoint, the ultrasonic pulse velocity for the density of $1,200 \mathrm{~kg} / \mathrm{m}^{3}$ was higher than that of the density of $600 \mathrm{~kg} / \mathrm{m}^{3}$. This is because the $1,200 \mathrm{~kg} / \mathrm{m}^{3}$ density LFC is better than that of $600 \mathrm{~kg} / \mathrm{m}^{3}$. LFC with higher air content tends to have larger air voids due to the proximity of the air voids, resulting in a higher incidence of void coalescing forming larger irregular air voids (Kim et al. 2010). A few larger pores are available, which is often due to the likelihood of the pores mixing and combining with higher levels of concrete foam (Kamaruddin et al. 2018).

According to Raj et al. (2020), the reduction in capillary void, entrained air void, entrapped air void, and water voids and other heterogeneities with the addition of OPMF increases the ultrasonic pulse velocity of LFC. The speed of wave propagation is subjected to the density of LFC and its flexible property. The pulse wave routes faster via a solid medium compared with fluid and gas media. Apart from that, the pulse wave is extremely complex and sensitive of changes in the medium, irrespective of whether it is by declining or elevating (Yerramala and Ramachandrudu 2016).

\section{CONCLUSION}

For this experimental study, the durability properties of LFC with the inclusion of different proportions of oil palm mesocarp fibre into different densities of LFC were carried out. Two densities of LFC, $600 \mathrm{~kg} / \mathrm{m}^{3}$ and $1,200 \mathrm{~kg} / \mathrm{m}^{3}$, were prepared and tested with five different percentages of OPMF added, namely $0.00 \%, 0.15 \%, 0.30 \%, 0.45 \%$, and $0.60 \%$. The experimental results revealed that the best outcomes, in terms of the durability properties (water absorption, porosity, drying shrinkage, and ultrasonic pulse velocity), were achieved with the optimum inclusion of a $0.45 \%$ volume fraction of OPMF for both densities considered in this research. At a $0.45 \%$ volume fraction of OPMF, the fibres and cementitious matrix attained a maximum compaction, which resulted in good mix homogeneity. Beyond the optimum level of the addition of OPMF, agglomeration and the non-uniform dispersion of fibres were observed, which led to reduction in all durability properties evaluated in this research.

\section{ACKNOWLEDGMENTS}

The author would like to thank Universiti Sains Malaysia for their funding of this research through the Bridging Grant No. 304/PPBGN/6316230.

\section{AUTHORS' CONTRIBUTIONS}

MAOM was solely involved in the study; from laboratory work, data analysis, manuscript writing, to final confirmation.

\section{COMPETING INTERESTS}

I hereby declare that there is no conflict of interest in the publication of this article.

\section{REFERENCES}

Amran YHM. 2020. Influence of structural parameters on the properties of fibred-foamed concrete. Innovative Infrastruct Solutions. 5(1):16. doi:10.1007/s41062-020 -0262-8.

Amran YHM, Farzadnia N, Abang Ali AA. 2015. Properties and applications of foamed concrete: a review. Constr Build Mater. 101:990-1005. doi:10.1016/j.conbuildmat. 2015.10.112.

Ardanuy M, Claramunt J, Toledo Filho RD. 2015. Cellulosic fiber reinforced cement-based composites: a review of recent research. Constr Build Mater. 79:115-128. doi: 10.1016/j.conbuildmat.2015.01.035.

ASTM C878/C878M-14a. 2014. Standard test method for restrained expansion of shrinkage-compensating concrete. West Conshohocken: ASTM International. doi: 10.1520/C0878_C0878M-14A.

Awang H, Ahmad MH. 2014. Durability properties of foamed concrete with fiber inclusion. Int J Civ Environ Eng. 8(3):273-276. doi:10.5281/zenodo.1091440.

Awang H, Ahmad MH, Al-Mulali MZ. 2015. Influence of kenaf and polypropylene fibres on mechanical and durability properties of fibre reinforced lightweight foamed concrete. J Eng Sci Technol. 10(4):496-508.

Balasubramanian M, Chandrashekaran J, Selvan SS. 2015. Experimental investigation of natural fiber reinforced concrete in construction industry. Int Res J Eng Technol. 02(01):179-182.

Bing C, Zhen W, Ning L. 2012. Experimental research on properties of high-strength foamed concrete. J Mater Civil Eng. 24(1):113-118. doi:10.1061/(ASCE)MT.1943-5 533.0000353.

British Standards Institution. 1983. BS 1881-122 testing concrete. Method for determination of water absorption. London: British Standards Institution.

British Standards Institution. 1996. BS 12: specification for Portland cement. London: British Standards Institution.

British Standards Institution. 2004. BS EN 12504-4:2004 testing concrete. Determination of ultrasonic pulse velocity. London: British Standards Institute.

Castillo-Lara JF, Flores-Johnson EA, Valadez-Gonzalez A, Herrera-Franco PJ, Carrillo JG, Gonzalez-Chi PI, Li QM. 2020. Mechanical properties of natural fiber reinforced 
foamed concrete. Materials. 13(14):3060. doi:10.3390/ ma13143060.

Claramunt J, Fernández-Carrasco LJ, Ventura H, Ardanuy M. 2016. Natural fiber nonwoven reinforced cement composites as sustainable materials for building envelopes. Constr Build Mater. 115:230-239. doi:10.1016/j.conbui ldmat.2016.04.044

Combrinck R, Boshoff WP. 2013. Typical plastic shrinkage cracking behaviour of concrete. Mag Concrete Res. 65(8):486-493.

Elsaid A, Dawood M, Seracino R, Bobko C. 2011. Mechanical properties of kenaf fiber reinforced concrete. Constr Build Mater. 25(4):1991-2001. doi:10.1016/j.conbuildma t.2010.11.052.

Falliano D, De Domenico D, Ricciardi G, Gugliandolo E. 2019. Compressive and flexural strength of fiber-reinforced foamed concrete: effect of fiber content, curing conditions and dry density. Constr Build Mater. 198:479-493. doi:10.1016/j.conbuildmat.2018.11.197.

Grégoire M, Ouagne P, Barthod-Malat B, Evon P, Labonne L, Placet V. 2019. Extraction of linseed flax fibres for technical textiles: influence of pre-treatment parameters on the fibre yield, the mechanical properties and the mechanical properties. Rev Compos Mater Av. 29(5):293-298. doi:10.18280/rcma.290503.

Hamad AJ. 2014. Materials, production, properties and application of aerated lightweight concrete: a review. Int J Mater Sci Eng. 2(2):152-157. doi:10.12720/ijmse.2.2.152 $-157$.

Hindy EE, Miao B, Chaallal O, Aitcin PC. 1994. Drying shrinkage of ready-mixed high-performance concrete. Mater J. 91(3):300-305. doi:10.14359/4292.

Jalal M, Tanveer A, Jagdeesh K, Ahmed F. 2017. Foam concrete. Int J Civ Eng Res. 8(1):1-14.

Jhatial AA, Inn GW, Mohamad N, Alengaram UJ, Mo KH, Abdullah R. 2017. Influence of polypropylene fibres on the tensile strength and thermal properties of various densities of foamed concrete. IOP Conf Ser: Mater Sci Eng. 271:012058. doi:10.1088/1757-899X/271/1/012058.

Kamaruddin S, Goh WI, Jhatial AA, Lakhiar MT. 2018. Chemical and fresh state properties of foamed concrete incorporating palm oil fuel ash and eggshell ash as cement replacement. Int J Eng Technol. 7(4.30):350. doi: 10.14419/ijet.v7i4.30.22307.

Kearsley EP, Wainwright PJ. 2001. Porosity and permeability of foamed concrete. Cem Concr Res. 31(5):805-812.

Kim YJ, Hu J, Lee SJ, You BH. 2010. Mechanical properties of fiber reinforced lightweight concrete containing surfactant. Adv Civ Eng. 2010:e549642. doi:10.1155/2010 $/ 549642$.

Lau Kt, Hung Py, Zhu MH, Hui D. 2018. Properties of natural fibre composites for structural engineering applications. Composites Part B. 136:222-233. doi:10.1016/j.co mpositesb.2017.10.038.

Mohamad N, Iman MA, Mydin MAO, Samad AAA, Rosli JA, Noorwirdawati A. 2018. Mechanical properties and flexure behaviour of lightweight foamed concrete incorporating coir fibre. IOP Conf Ser: Earth Environ Sci. 140:012140. doi:10.1088/1755-1315/140/1/012140.

Moses OT, Samson D, Waila OM. 2015. Compressive strength characteristics of kenaf fibre reinforced cement mortar. Adv Mater. 4(1):6. doi:10.11648/j.am.2015 0401.12.

Musa M, Mydin MAO, Ghani ANA. 2019. Thermal properties of foamed concrete with addition of empty fruit bunch (EFB) fiber. Int J Innovative Technol Explor Eng. 8(10):4662-4670. doi:10.35940/ijitee.J1081.0881019.

Mydin MAO. 2016. Evaluation of splitting tensile strength in plain and fibre-reinforced foamed mortar. Jurnal Teknologi. 78(5):413-419. doi:10.11113/jt.v78.8346.

Mydin MAO, Phius AF, Sani NM, Tawil NM. 2014. Potential of green construction in Malaysia: industrialised building system (IBS) vs traditional construction method. E3S Web Conf. 3:01009. doi:10.1051/e3sconf/20140301009.

Mydin MAO, Zamzani NM. 2018. Coconut fiber strengthen high performance concrete: Young's modulus, ultrasonic pulse velocity and ductility properties. Int J Eng Technol. 7(2.23):284-287. doi:10.14419/ijet.v7i2.23.11933.

Mydin MAO, Zamzani NM, Ghani ANA. 2018. Effect of alkaliactivated sodium hydroxide treatment of coconut fiber on mechanical properties of lightweight foamed concrete. AIP Conf Proc. 2016(1):020108. doi:10.1063/1.50 55510.

Nambiar E, Ramamurthy K. 2007. Sorption characteristics of foam concrete. Cem Concr Res. 37:1341-1347. doi: 10.1016/j.cemconres.2007.05.010.

Rahman MR, Huque MM, Islam MN, Hasan M. 2008. Improvement of physico-mechanical properties of jute fiber reinforced polypropylene composites by posttreatment. Composites Part A. 39(11):1739-1747. doi: 10.1016/j.compositesa.2008.08.002.

Raj A, Sathyan D, Mini KM. 2019. Physical and functional characteristics of foam concrete: a review. Constr Build Mater. 221:787-799. doi:10.1016/j.conbuildmat. 2019.06.052.

Raj B, Sathyan D, Madhavan MK, Raj A. 2020. Mechanical and durability properties of hybrid fiber reinforced foam concrete. Constr Build Mater. 245:118373. doi: 10.1016/j.conbuildmat.2020.118373.

Ramli M, Kwan WH, Abas NF. 2013. Strength and durability of coconut-fiber-reinforced concrete in aggressive environments. Constr Build Mater. 38:554-566. doi:10.1016/j.conbuildmat.2012.09.002.

Risdanareni P, Sulton M, Nastiti SF. 2016. Lightweight foamed concrete for prefabricated house. AIP Conf Proc. 1778(1):030029. doi:10.1063/1.4965763.

Serri E, Suleiman MZ, Mydin MAO. 2014. The effects of oil palm shell aggregate shape on the thermal properties and density of concrete. Adv Mat Res. 935:172-175. doi: 10.4028/www.scientific.net/amr.935.172.

Suhaili SS, Mydin MAO. 2020. Potential of stalk and spikelets of empty fruit bunch fibres on mechanical properties of lightweight foamed concrete. Int J Sci Technol Res. 9(3):3199-3204.

Yerramala A, Ramachandrudu C. 2016. Properties of foamed concrete with sisal fibre. Paper presented at: 9th International Concrete Conference 2016, Environment, Efficiency and Economic Challenges for Concrete; Dundee, Scotland. p. 656-669.

Yusoff MZM, Salit MS, Ismail N, Wirawan R. 2010. Mechanical properties of short random oil palm fibre reinforced epoxy composites. Sains Malays. 39(1):87-92.

Zamzani NM. 2019. Characterization of durability and mechanical properties of 'Cocos nucifera Linn' fibre (CNF) reinforced foamcrete and its performance at elevated temperatures [Master's thesis]. [Penang]: Universiti Sains Malaysia. http://eprints.usm.my/46610/.

Zhang J, Stang H, Li VC. 2001. Crack bridging model for fibre reinforced concrete under fatigue tension. Int J Fatigue. 23(8):655-670. doi:10.1016/S0142-1123(01)00041-X. 